\title{
KAZIMIR MALEVICH'S SUPREMATISM AND MODERNIST ARTISTIC MYTHOLOGY AS AN ALTERNATIVE TO RELIGION
}

The present paper discusses the religious and mythological aspects of the Suprematism of Kazimir Malevich (1879-1935). The purpose is to not to provide a detailed overview of Malevich's artistic practices and conception of Suprematism, but to thematise their tendency towards mythologising. Suprematism radically changed the means of expression of visual art at the beginning of the $20^{\text {th }}$ century, cutting off all connections with mimetic art and starting from scratch with the "language" of pure geometric forms. Therefore (and especially from the viewpoint of the current journal's central issue, dedicated to the relations of art and religion), of special interest is the fact that the formal innovations of Suprematism were motivated by impulses related to religious and, more broadly, mythological thinking.

Suprematism was not just a new aesthetic system, but strove for a total transformation of the world: within its ambition to perform as a model of world order lay a wish to take over a fundamental function of religion and mythology. Malevich positioned his art conception ambitiously for a universal aesthetic-philosophical system, dwelling on his ideas, which were imbued with prophetic pathos and seen by him nearly as revelations. This suggests a case study of relations between modernism and religion, which were not direct, but implicit, and they can be viewed as religiosity in the broad sense rather than a connection with a particular religion (Christianity or Buddhism). The purpose of artistic 
searches that arose at the beginning of the $20^{\text {th }}$ century - foremost those connected to the development of an abstract method of depiction, e.g. the synaesthetic abstract painting of Wassily Kandinsky, abstractions of František Kupka and the Neoplasticism of Piet Mondrian - was a spirituality beyond the realms of the art sphere, which in its most radical forms claimed to be absolute truth.

Opposing the Nietzschean statement of the death of God, Malevich wrote that "God is not cast down"1, but he searched for God not so much in Christianity as in himself and his art ${ }^{2}$, transforming Suprematism into a kind of personal religion. Furthermore, I prefer to use the notion of artistic mythology rather than that of (personal) religion, engaging in discussion aspects from different mythological systems, and from traditional and contemporary collective myths.

\section{BACKGROUND: MODERNIST SEARCH FOR}

\section{A UNIVERSAL “LANGUAGE" IN ART}

Suprematism was not a unique phenomenon of its time. At the beginning of the $20^{\text {th }}$ century in Russia, a number of art conceptions sprang up that broke with the realist paradigm and purported universality: Wassily Kandinsky's programme of abstract art, Pavel Filonov's "analytical art", Vladimir Tatlin's utopian constructing, the utilitarian industrial art of the Constructivists etc. However, Suprematism was distinct in its extreme absolutism: as I will discuss later, Malevich's visions foresaw transformations, according to the Suprematist model, not only of cities, but also of nature and cosmic space. Although the modernist myth of the artist-creator was also a catalyst for Futurism, Neoplasticism and Bauhaus in the West, the Russian avant-garde was exceptional because of its socio-political context: it had the opportunity to move from a revolution in art to the social revolution of 1917 and test ideas in real life and in public

1 His tract from 1922 was entitled "God is not Cast Down. Art, Church, Factory" "“Бог не скинут. Искусство, церковь, фабрика”). Sее: Казимир Малевич, Собрание сочинений в пяти томах, Т. 1 (Москва: Гилея, 1995), 236-265. English translation quoted from: http://www.scribd.com/ doc/149667662/Malevich-God-is-Not-Cast-Down (accessed on 20.08.2014).

2 From Malevich's poem of 1913: "I am the beginning of everything for in my consciousness worlds are created. I search for God. I search within myself for myself." "Я Начало всего, ибо в сознании моем создаются миры. Я ищу Бога я ищу в себе себя.”) Казимир Малевич, “Статьи, манифесты, записи и заметки”, Казимир Малевич: Живопись. Теория (Москва: Искусство, 1993), 373. English translation quoted from: Kazimir Malevich: The Artist, Infinity, Suprematism, Unpublished Writings 1913-1933, ed. Troels Andersen (Copenhagen: Borgens Vorlag, 1978), 189-190. 
space, and on an unprecedented scale. Due to historical events, in Russia a big societal myth and a myth of art came into extraordinary resonance.

The atmosphere of desire for world renewal, which was dominant between the revolutions of 1905 and 1917, encouraged cultural innovations as well. A number of ambitious projects evolved that sought to create a new, free from old restrictions, self-sufficient and universal "art language" ${ }^{3}$, which would lead to art and culture of a new type, as well as generating a new society. There are also patterns of the myth of the perfect language, belief in the possibility of a universal language that would capture the true essence of things and embrace all life, as had the divine language lost after the Golden $\mathrm{Age}^{4}$, of which the absolute manifestation are the words of God that become matter in the act of Creation. This mythologeme was transformed into belief in a universal art language, into which was integrated the modernist myth of the artist's ability to create new aesthetic principles for the positive transformation of reality. These ideas, in turn, reflected the big narratives of the period. Eschatological moods, mixed with the myth of progress, were accompanied by the belief in the necessity of a new start: the ideology of revolution preached the need to destroy the old unjust capitalist world in order to create a new communist society, based on equality ${ }^{5}$.

Similar eschatological moods prevailed in the conceptions of the new art of the time, appealing to the radical innovation of forms. New better art was imagined to be possible only after a total destruction of traditional forms, bringing visual expression to the level of primeval chaos and elementary particles, in order to start creating the new art syntax

3 See Malevich's statement: “All former and contemporary painting before suprematism, and sculpture, the word, and music were enslaved by the form of nature, and they await their liberation in order to speak in their own tongue and not depend upon the intellect, sense, logic, philosophy, psychology, the various laws of causality and technical changes in life.” “"Вся бывшая и современная живопись до супрематизма, скульптура, слово, музыка были закрепощены формой натуры и ждут своего освобождения, чтобы говорить на своем собственном языке и не зависеть от разума, смысла, логики, философии, психологии, разных законов причинности и технических изменений жизни.”) Казимир Малевич, “От кубизма к супрематизму. Новый живописный реализм” (published in 1916), Казимир Малевич, Собрание сочинений в пяти томах, 27. English translation quoted from: Kazimir Malevich, "From Cubism to Suprematism in Art, to the New Realism of Painting, to Absolute Creation", Swans of Other Worlds: Kazimir Malevich and the Origins of Abstraction in Russia, ed. Charlotte Douglas, 107.

4 See Umberto Eco, The Search for the Perfect Language (London: Fontana Press, 1997).

5 Mythological patterns of the Marxist idea of revolution, which became dominant due to the Bolsheviks' rise to power after the revolution of 1917, have been demonstrated by the historian of religion Mircea Eliade, who compared conceptions of revolution and the Apocalypse: Мирча Элиаде, Аспекты мифа (Москва: Парадигма, 2005), 69. 
from scratch. At the beginning of the 1910s in Russian painting several versions of abstract art evolved that operated with "visual elementary particles": the first of them were the expressive abstract paintings of Wassily Kandinsky and the Rayonism of Mikhail Larionov.

After Larionov left for Paris in the middle of the decade, Malevich took over the role of the leader of Russian experimental art. Having acquired in a short time experience with both traditional and modern painting, from Impressionism and Symbolism to Primitivism and Cubofuturism, Malevich stood as a heroic figure embodying the extraordinariness of the Russian avant-garde: his individual evolution was composed of several stages of development that would require more time in other national artistic schools ${ }^{6}$. After passing through that phase, he was ready to start working on his own artistic system. But for that purpose he had to overcome a common way of thinking and move toward a new logic. At first, this was the method of "Alogism": play with words and images that defied common logic.

Malevich's "Alogistic" works juggled whole or fragmented images, words, collages, found objects and confusing titles. ${ }^{7}$ In his practices of Alogism, important roles were played by Malevich's contacts with the Futurist poets Velimir Khlebnikov and Aleksei Krutchenykh, whose experiments with creating new words and linguistic structures came to be called zaum. ${ }^{8}$ Zaum was seen as a higher level of consciousness, which extended beyond common logic and reason; the language of zaum was supposed to be the transcendent language of the future. ${ }^{9}$ Experiments with zaum inspired Malevich's Alogistic exercises in painting and soon he came up with a new visual system, where the basic structure was the geometric figure.

\section{THE BIRTH OF SUPREMATISM}

The collaboration of zaum poets with Malevich, as well as with the painter and composer Mikhail Matyushin, culminated in the Futurist opera Victory over the Sun («Победа над Солнцем», 1913), which manifested

6 Евгений Ковтун, “Путь Малевича", Казимир Малевич 1878-1935 (Амстердам: Stedelijk Museum, 1988), 69.

7 Charlotte Douglas, "Beyond Reason: Malevich, Matiushin, and Their Circles", The Spiritual in Art: Abstract Painting 1890-1985 (New York: Abbeville Press, 1986), 188.

8 Селим Хан-Магомедов, Казимир Малевич (Москва: Русский авангард, 2010), 29. In Russian "zaum" means "supreme mind", but also "beyond mind" or "beyond reason".

9 Douglas, "Beyond Reason”, 187. 
avant-garde mythology in the form of a total artwork. Reflecting the myth of progress, the belief that the development of science and technology would bring about total control over Nature, the Sun embodied obsolete earthly logic and the old world, and imperfect sunlight was replaced by human-created electric light. The opera glorified technology and its victory over biological and cosmic forces; this victory was associated with unprecedented freedom and rational construction of a new world. The authors praised the building of the new world by destroying the old one, and the opera itself was alogical and chaotic, suggesting the atmosphere of the end of the world. ${ }^{10}$ The stage and costume designs were made by Malevich, still in a Cubist manner, but in the stage design the prototype of the famous Black Square appeared for the first time: it symbolised the victory of active human creation over passive nature, as the black square replaced the disc of the Sun.

Malevich consciously developed those intuited ideas of Suprematism during the next two years. He prepared an exhibition set of Suprematist paintings and formulated a theoretical basis, his Suprematist manifesto. The term Suprematism, which Malevich derived from his mother tongue ${ }^{11}$, reflected his ambition of creating a supreme system of art. In The Last Futurist Exhibition of Paintings 0,10 [zero-ten] («Последняя футуристическая выставка картин 0,10 [ноль-десять]») from December 1915 to January 1916 in Petrograd, Malevich presented 49 Suprematist paintings, among them the Black Square (1915), the visual manifesto of Suprematism. The title of the exhibition reflected the organisers' wish to nullify all art and start counting new art from zero. ${ }^{12}$ This privilege Malevich ascribed above all to himself: "The striving of the artistic powers to direct art along the path of intellect produced a zero of creativity. [...] But I have transformed myself into a zero of form and gone beyond 0 to $1 .{ }^{\prime 13}$ This conception, seen by the author as a sort of revelation, was not intended merely for personal use. According to Malevich, everyone striving for fundamental renewal of art and culture should follow it: "Suprematism is the beginning of a

10 Хан-Магомедов, Казимир Малевич, 31; Натэлла Енукидзе, “«Победа над солнцем» наяву”, Искусство авангарда: язык мирового общения (Уфа: Восток, 1993), 84.

11 "Supremacija" in Polish means "supremacy", "dominance", "superiority".

12 Ковтун, “Путь Малевича", 156-157.

13 "Усилие художественных авторитетов направить искусство по пути здравого смысла - дало нуль творчества. [...] Но я преобразился в нуле форм и вышел за 0-1.” Малевич, “От кубизма к супрематизму", 34. English translation quoted from: Kazimir Malevich, "From Cubism to Suprematism", Swans of Other Worlds: Kazimir Malevich and the Origins of Abstraction in Russia, ed. Charlotte Douglas, 107-110. 
Fig. 1. Kazimir Malevich's works at the exhibition „The Last Furutist Exhibition of Paintings $1.10^{\prime \prime}$ in the art Bureau of N. Dobychina (December 1915 - January 1916, Petrograd). Central State Archives of Cinema, Photo and Phono Documents of Saint Petersburg, Д 3539.

new culture [...]. You are caught in the nets of the horizon, like fish! We, suprematists, throw open the way to you. Hurry!"14 In these words, we hear the pathos of the infallible truth: for Malevich, Suprematism was a kind of universal cosmic principle that had to be followed unconditionally. According to Malevich, the superiority of Suprematism consisted in overcoming the idea of mimesis, setting itself free from plot and depiction of objects of reality. Malevich saw his compositions, which were based on monochromatic geometric shapes, as autonomous from nature, where every painting created a sovereign ideal world: "Our world of art has become new, nonobjective, pure. Everything has disappeared; a mass of material is left from which a new form will be built. In the art of Suprematism, forms will live, like all living forms of nature. [...] Each

14 “Супрематизм - начало новой культуры [...]. Вы в сетях горизонта, как рыбы! Мы, супрематисты, - бросаем вам дорогу. Спешите!” Малевич, “От кубизма и футуризма к супрематизму”, Казимир Малевич, Собрание сочинений в пяти томах, 53, 55. English translation quoted from: Kazimir Malevich, "From Cubism and Futurism to Suprematism", Russian Art of the Avant-Garde: Theory and Criticism 1902-1934, ed. John E. Bowlt (London: Thames and Hudson, 1991), 133, 135. 
form is free and individual. Each form is a world."15 Malevich considered Suprematism to be a universal aesthetics, which would embrace poetry, music, theatre and sculpture: "Artists-Suprematists just came through the path of revolution in the state of art and got around to creation, i.e. they have now become a part of one universal law of nature". ${ }^{16}$ For its founder, Suprematism offered a potential to create new phenomena, which would resemble the absolute laws of nature.

\section{MYSTICAL ASPECTS OF THE AVANT-GARDE AND SUPREMATISM'S CONNECTIONS WITH ESOTERICISM}

Malevich and his contemporaries' desire to get to the basic structures of art, as well as the passion to depict processes invisible to the unequipped eye, was connected to the scientific developments of the period: constant improvements in the microscope and telescope, as well as the invention of the $x$-ray machine, made it possible to see what the human eye could not see. The evolution of abstract art has been associated by researchers with the new world-view, which expanded both on the micro- and macro-levels: in their works, artists strove to unveil structures and processes invisible to the unequipped eye by the method of art. In this, they came across problems of both the material and immaterial, invisible worlds.

To the common consciousness, $x$-rays, electric power and the magnetic field were immaterial forces, which were able to pass through solid bodies. In this world of "energies" delivered by science, solid bodies and objects of certain shapes had suddenly become uncertain. The scientific perception of the world of this period resembled the philosophical world-view of Romanticism, in which matter and spirit, the "energy of life", are dynamically and inseparably bound. This fact disproves the previously rooted idea of the avant-garde as a harbinger of the foremost objective scientific and technological world. Charlotte Douglas, who has explored connections between the avant-garde and mysticism, writes

15 "Наш мир искусства стал новым, беспредметным, чистым. Исчезло все, осталась масса материала, из которого будет строиться новая форма. [...] Каждая форма свободна и индивидуальна. Каждая форма есть мир." Ibid, 53. English translation quoted from: Malevich, "From Cubism and Futurism to Suprematism", 133, 134.

16 "Художники-супрематисты только прошли путь революции в государстве искусства и вышли к творчеству, т.е. приобщились теперь к одному вселенскому закону природы.” Казимир Малевич, "Родоначало супрематиума” (published in 1918), Казимир Малевич, Собрание сочинений в пяти томах, 111. 
that during that period there was a popular belief that those with more developed cognitive ability could also perceive subtle energy, a sort of fourth dimension; in Malevich's late Suprematist works, Douglas sees attempts to depict cosmic energies. ${ }^{17}$

Russian culture at the beginning of the $20^{\text {th }}$ century was pervaded with ideas related to mysticism and esotericism, with which avant-garde artists had a certain contact, though indirectly - through materials published in Symbolist journals, and discussions in home salons - rather than by attending lectures or reading texts which introduced Theosophy, Anthroposophy, Hermetic doctrine or Eastern philosophy. Another researcher of the Russian avant-garde, John Bowlt, stresses that Malevich borrowed the ideas of Suprematism that can be associated with esotericism rather sporadically, not as a result of consistent study. Although the desire to depict the invisible world in abstract painting has a lot in common with Rudolf Steiner's or Helena Blavatsky's aspirations to get to know higher reality or the inner human cosmos, for example, these should be seen as indirect influences. Still, those ideas "floating in the air", whose origin is difficult to trace, were the reasons why the Russian avant-garde artists associated abstract art with the "new human" and the world of the future, where painting would be equal to a divine act. ${ }^{18}$

Bowlt also connects the mystic moods of the time with the obsession with the void of the avant-garde artists. The conception of the void, which originated in Eastern philosophy, was acknowledged through secondary sources, and even in Malevich's formula of Suprematist painting certain parallels with the conception of Nirvana as a final dissolving of matter can be discerned..$^{19}$ Indeed, in Malevich's texts descriptions can be found that are similar to the conception of the Nirvana state: "Man on achieving perfection immediately retires into rest, i.e. the absolute; he is freed from understanding knowledge, and various proofs [...]."20 Still, there follows the statement that: "It may be taken as a mark of the perfection of universal world-movement or God that man himself has

17 Шарлотта Дуглас, "К вопросу о философских истоках беспредметного искусства", Малевич: Художник и теоретик (Москва: Советский художник, 1990), 57-60.

18 John E. Bowlt, "Esoteric Culture and Russian Society", The Spiritual in Art: Abstract Painting 1890-1985 (New York: Abbeville Press, 1986), 165-179.

19 Ibid, 174-176.

20 "Человек достигший совершенства одновременно уходит в покой т. е. абсолют, освобождается от познаний, знаний и разных доказательств [...]." Малевич, "Бог не скинут", 257. English translation quoted from: http://www.scribd.com/doc/149667662/Malevich-God-is-NotCast-Down (accessed on 22.08.2014). 
discovered that nothing disappears but merely takes on a new form." ${ }^{21}$ This is a reference to the law of conservation of energy, and demonstrates how Malevich blended ideas from different world-views.

This prophetic pathos was conditioned by the mental climate of the period, which attributed special abilities to the artist because in the Russian intellectual environment of the time the tenets of Positivist philosophy were quite weak. In the last decades of the $19^{\text {th }}$ century, Russian religious philosophers had protested against the growing influence of Positivism. In the conception of "all-unity" of Vladimir Solovyov, the spiritual and material worlds were inseparable and truth was revealed only in the synthesis of empirical, philosophical-rational and mystical ways of cognition. According to Solovyov, "all-unity" - considered as absolute well-being, truth and beauty - became matter specifically through art ${ }^{22}$. During the discussed period, representatives of different cultural fields revealed a belief that art intuited new ideas much earlier than philosophy or science, but delivered them in a different form, which abandoned logic. In the method of the avant-garde, which valued both intuition and rational comprehension, and strove for a synthesis that would express the wholeness of existence, some parallels with the ideas of world synthesis can be seen. The role of art and the artist was also emphasized by Nikolai Berdyaev's conception of antropodicea ${ }^{23}$, the idea of the justification of a man by creative work: the act of creation accomplished jointly with God. The Christian mission of redemption was replaced here by the mission of creative work, which led to the conception of art as life-building (жизнестроение). ${ }^{24}$

\section{ICONIC PRACTICES OF SUPREMATISM}

Thus, the entire intellectual context encouraged the messianic role of the artist. The avant-garde artists saw themselves as prophets of the

\footnotetext{
21 “Совершенством вселенного миродвижения или Бога, можно считать то, что самим человеком обнаружено доказательство того, что ничего не исчезает в ней, только принимает новый вид." Ibid, 264. English translation quoted from: http://www.scribd.com/doc/149667662/ Malevich-God-is-Not-Cast-Down (accessed on 22.08.2014).

22 See, for example: Владимир Соловьев, “Общий смысл искусства”, Владимир Соловьев, Философия искусства и литературная критика (Москва: Искусство, 1991), 73-89.

23 See, for example: Николай Бердяев, “Смысл творчества”, Николай Бердяев, Философия творчества, культуры и искусства. Т. 1 (Москва: Искусство, 1994), 108-124.

24 Дмитрий Сарабьянов, “Русский авангард перед лицом религиозно-философской мысли”, Искусство авангарда: язык мирового общения (Уфа: Восток, 1993), 6-18.
} 
new art, which was praised by them as a kind of new religion, requiring new "icons". An important role was played by the visual world of the old Russian icons that was rediscovered under overpaintings at the beginning of the $20^{\text {th }}$ century and became a significant point of departure for developing the painterly language of the Russian avant-garde. Besides the formal means of expression, an influential factor was the semantics of icons: the emphasised conventionality of the images of the divine world, symbolic "flatness" coinciding with the ambition to accomplish the higher reality of avant-garde artists. Here, the everlasting problem of sacral art arose: to depict the undepictable, to show the invisible. Natalia Goncharova and Mikhail Larionov were the first ones to adopt the language of icon painting in their works, but very soon this method was picked up by Suprematism as well, where the rhetoric of the icon was, typically for Malevich, brought to the absolutising level.

The Black Square of Malevich became unquestionably the most important "icon" of the avant-garde. Everything in this painting - colour, shape and structure - is reduced to zero, as if the artist has started solemnly creating new worlds from "nothing" 25 . Malevich himself praised this painting as the highest revelation, and even a living being: "The square is a living royal infant. It is the first step of pure creation in art. Before it, there were naive deformities and copies of nature." ${ }^{26}$ The Black Square was not just a challenge to the public, but a sign of a quaint searching for God and a symbol of Suprematism, positioned as a new religion.

As Malevich's philosophical absolute, the Black Square took the form of the incomprehensible Nothing, which symbolised and embodied the world vacuum, the beginning and the end of the Universe. The Black Square brought its author to the "risky contemplation of All and Nothing" ${ }^{\prime 27}$, which is described by Malevich very suggestively as a deeply mystical experience: "I have been at the beginning of the beginnings and, having reached the Suprematist surface shaped by the square, coined my face". ${ }^{28}$ Malevich said that after finishing the Black Square,

25 Евгений Ковтун, "Начало супрематизма", Малевич: Художник и теоретик (Москва: Советский художник, 1990), 105.

26 “Квадрат живой, царственный младенец. Первый шаг чистого творчества в искусстве. До него были наивные уродства и копии натуры." Малевич, “От кубизма и футуризма к супрематизму", 53. English translation quoted from: Malevich, "From Cubism and Futurism to Suprematism", 133.

27 Ковтун, “Путь Малевича", 69.

28 Казимир Малевич, “Государственникам от искусства” (published in 1918), Казимир Малевич,

Собрание сочинений в пяти томах, 82. 
Fig 2. Room with Kazimir Malevich's works at the exhibition "Artists of the RSFSR over 15 Years". (State Russian Museum. 1932. Republished from: Приключения «Черного квадрата» (Saint Petersburg: Palace Editions, 2007), p. 56).

he could not eat or sleep for a week ${ }^{29}$, such a strong influence his own invention had had on him. Here, the autobiographical narrative of the artist was interwoven with the motif of the myth of creation, in which the demiurge, standing at the beginning of time, created first himself and then - in his own image - the whole world.

The role of Suprematist paintings as manifestations of the new, higher reality was stressed by the mode in which they were exhibited. The formal resemblance between Malevich's works and icons soon developed into total equation: the self-sufficient Black Square was not a depiction of reality, but was established by the author as the Suprematist reality itself. At the Last Futurist Exhibition in 1915, Malevich exhibited the Black Square under the ceiling, above all the other works, clearly referring to the icon corner of the Russian Orthodox tradition. Malevich often displayed his works in several rows, which could be interpreted

29 Татьяна Горячева, “Почти все о «Черном квадрате»", Приключения «черного квадрата» (Санкт-Петербург: Palace Editions, 2007), 18. 
as an imitation of the Orthodox iconostasis: the result was a suggestive "membrane" between visible and invisible reality ${ }^{30}$.

A vivid example of this exhibiting practice was the display of Malevich's works at the exhibition of the State Institute of Artistic Culture in 1926 in Leningrad. The Suprematist "Holy Trinity" - Black Cross, Black Circle and Black Square, which also have connotations from Christian symbolism - was exhibited above the architectons ("formulae" of Suprematist universal architecture), resembling an Orthodox iconostasis or Lutheran altar. The display of Malevich's works at the exhibition Artists of the RSFSR over 15 years (1932) was structured according to the same principle. Above the group of architectons embodying a city of the future were placed three paintings, in the compositions of which the motif of the cross was central: for Malevich, more than a Christian symbol, it was a universal Suprematist "sign". Thus, the exhibition space became sacred and the viewer became a participant in an initiation into mysteries: ritualising profane exhibition, Malevich constructed the reception of his works as sacred objects.

\section{SUPREMATISM CREATING NEW LIVING SPACE}

Malevich's experiments tested the limits of painting. In 1910 he abandoned painting for some time, dedicating himself to theoretical work and developing the potential of Suprematism in other fields. Instead of making design or architecture objects, he proposed a total Suprematism model for organising both intrapictorial and extrapictorial space, in two or three dimensions, regardless of the scale or function. In 1919 he was invited to teach in the Vitebsk People's Art School, where the director was Marc Chagall. Malevich soon became the new leader of the school, around whom formed a group of followers, UNOVIS ${ }^{31}$.

In 1919-1922 the members of UNOVIS completed numerous projects in Vitebsk city space, commissioned by the Soviet authorities. Trams, interiors of canteens and reading rooms, tribunes and façades of buildings were decorated in a Suprematist manner. Suprematist decoration invaded shop signs, posters, book covers, textiles, flowerpots and furniture: Suprematism was attempting to enter the world of three-dimensional

30 Andrew Spira, The Avant-Garde Icon: Russian Avant-Garde and the Icon Painting Tradition (Aldershot, Burlington: Lund Humphries: 2008), 139-145.

31 “Утвердители Нового Искусства" or the "Affirmers of the New Art". 


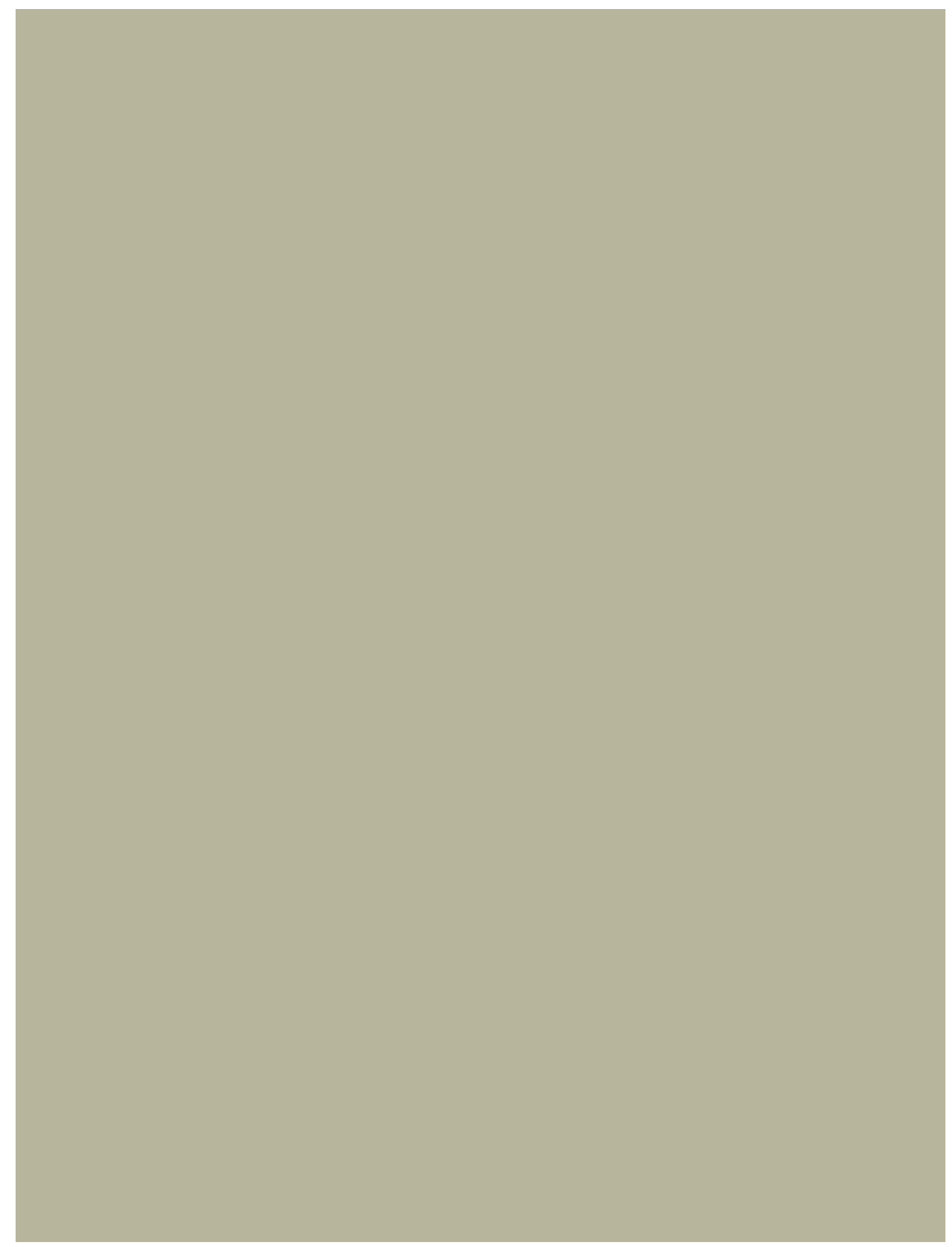

Fig. 3. At the workshop of UNOVIS in Vitebsk. 1921. On the foreground Nikolai Suetin, at the blackboard Kazimir Malevich. (Republished from: Приключения «Черного квадрата» (Saint Petersburg: Palace Editions, 2007), p. 64). 
objects, though at first as three-dimensional ornaments ${ }^{32}$. The expansion of Suprematism into multiplied objects and public space meant the expansion of its means of communication, with the purpose of introducing the Suprematist system, but also its direct accomplishments.

Concurrently, some attempts to create three-dimensional Suprematist forms took place. In 1923 Malevich introduced architectons, which were for him real projects of a big new style: he presumed that the "Suprematist order" would be able to shape all the spheres of intellectual and material life of humankind ${ }^{33}$. But Malevich described cities as only minor elements on the Suprematist surface of the Earth and dreamt of a supreme city ${ }^{34}$. His all-encompassing ambition went beyond cities, and he expressed a wish to replace existing nature with a Suprematist one: "Our globe, the surface of the Earth, is disorganised. [...] There exists some nature, but I want to instead create Suprematist nature, which will be built according to the Suprematist laws." ${ }^{35}$ Thus, the goal of Suprematism was to accomplish the harmony of the Universe in a better way than nature itself had. Here was not just an artist-prophet, but a visionary with ambitions of a demiurge: "We, Suprematists, announce our primacy because we have recognised ourselves as the source of the creation of the world [...]."36

At the same time, Malevich was working on "planits", a project of "supra-architecture": floating cities or space ships, which lunged from the surface of the Earth into the cosmos. Malevich's dreams of space travel started in the 1910s and in his descriptions can be found some resemblance with the ideas of Konstantin Tsiolkovsky, for whom the father of Malevich's pupil Ivan Kudryavtsev worked. In 1903 Tsiolkovsky was the first to scientifically verify the possibility of using rockets in open space. Mystical thinking was not alien to Tsiolkovsky and he claimed that his spiritual father was Nikolai Fyodorov, a philosopher-cosmicist of the end of the $19^{\text {th }}$ century, who wrote about the necessity of conquer-

32 Хан-Магомедов, “Казимир Малевич”, 162-163.

33 Александра Шатских, “Слово Казимира Малевича”, Казимир Малевич, Собрание сочинений в пяти томах, 15.

34 Казимир Малевич, “О новых системах в искусстве” (published in 1919), Казимир Малевич, Собрание сочинений в пяти томах, 181-182.

35 “Наш земной шар, земная поверхность не организована. [...] Существует какая-то природа, я хочу вместо этой природы создать супрематическую природу, построенную по законам супрематизма." From Malevich's conversation with Osip Brik (December 1921), see: Хан-Магомедов, “Казимир Малевич”, 193.

36 “Мы, супрематисты, заявляем о своем первенстве, ибо признали себя источником творения мира [...].” Казимир Малевич, “Я пришел” (published in 1918), Казимир Малевич, Собрание сочинений в пяти томах, 108. 
ing space. Malevich's idea of the functioning of his spacecraft was not based on technological arguments: those perfect Suprematist forms were supposed to fit harmoniously into the processes of nature. ${ }^{37}$

According to Evgeny Kovtun, Malevich was the first to use the word "Sputnik" in referring to an artificial satellite, signifying an aircraft for interplanetary travel, whereby its conception was derived by Malevich purely from Suprematist principles: "In this manner, Suprematism is established in relation to the earth; but because of its economic construction, it transforms all the architecture of the objects of earth, uniting - in the broadest sense of the word - with the space of the moving monolithic masses of the planetary system. During my research, I discovered that Suprematism contains the idea of a new machine: i.e. a new organismic motor which does not need wheels, steel or gasoline." ${ }^{38}$ Analysing the relations between the Earth and the Moon from the viewpoint of the laws of Suprematism, Malevich proposed the creation of a special orbit between the Earth and the Moon, intended for an artificial satellite of the Earth, as well as suggested a scheme of flight from the Earth to other planets $^{39}$. Suprematist practices transcended the borders between three distinct word-views - science, art and religion ${ }^{40}$ - revealing syncretism, which is characteristic of mythological thinking.

\section{THE AUTOBIOGRAPHICAL MYTH OF MALEVICH}

Malevich was convinced that Suprematism was the only right way and there was a major confrontation between him and other great figures of the Russian avant-garde, including Vladimir Tatlin, who suggested no less absolute systems. The competition between the leaders of the Russian avant-garde is expressed in the stories related to the rivalry

\footnotetext{
37 Charlotte Douglas, Kazimir Malevich (London: Thames and Hudson, 1994), 26-27.

38 “Таким образом, супрематизм устанавливает связи с Землею, но в силу экономических своих построений изменяет всю архитектуру вещей Земли, в мирском смысле слова соединяясь с пространством движущихся однолитных масс планетной системы. При исследовании обнаружил, что в супрематизме лежит идея новой машины, т.е. нового бесколесного беспаробензинного двигателя организма.” Казимир Малевич, “Супрематизм. 34 рисунка” (published in 1920), Казимир Малевич, Собрание сочинений в пяти томах, 188. English translation quoted from: Kazimir Malevich, Suprematism: 34 Drawings (London: Gordon Fraser Gallery, 1974), online version http://books.google.ee/books?id=gCdQAAAAMAAJ\&dq=inauthor\%3A\%22Kazim ir\%20Severinovich\%20Malevich\%22\&source=gbs_similarbooks (accessed on 22.08.2014).

39 Ibid.

40 Хан-Магомедов, “Казимир Малевич”, 200.
} 
between Malevich and Vladimir Tatlin. In the writings of the contemporary art historian Nikolai Punin, this conflict took a mythologised form: "Theirs was a special fate. When it started, I do not know, but as long as I knew them, they divided the world between themselves: the earth and the sky and interplanetary space, establishing their spheres of influence everywhere. Tatlin usually secured the earth and attempted to push Malevich into the sky for non-objectivism. Malevich, while he did not reject the planets, would not concede the earth, justly presuming that it, too, was a planet and could therefore be non-objective." ${ }^{\prime 41}$ Punin's vivid description suited the narrative of the epic division of the universe into spheres of influence between ancient gods and demonstrated the presence of the mythological discourse in the art reception of the time.

In the process of self-mythologising, Malevich positioned himself as an ontological unit, whose task was to create not merely an individual existence, but actual being: he was "the artist-prophet, who would dictate to the world its shape" ${ }^{\prime \prime 2}$. Malevich developed his autobiographical myth by constructing self-representation: in somewhat naively self-affirming early self-portraits and late majestic self-portraits, as well as in photographs, where he posed in a role filled with pathos. Malevich had extraordinary charisma; he was always surrounded by devoted pupils, who saw him as a real "commander" and a "leader", in the terms of the revolutionary rhetoric of the time. Malevich used Suprematist symbolism in everyday situations as well: when he signed his letters and paintings, in addition to his name, he added the image of a black square. Malevich and his pupils wore black squares on their sleeves, as a sign of devotion to the mysteries of Suprematism. ${ }^{43}$ Likewise in his exhibitions, Malevich ritualised his own and his pupils' everyday lives through Suprematist symbols.

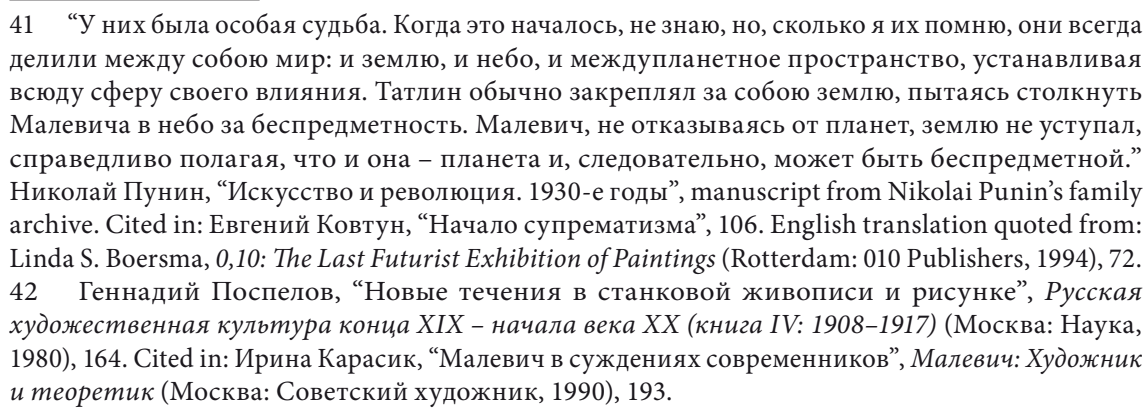

43 Карасик, “Малевич в суждениях современников”, 194. 
Fig. 4. UNOVIS departing to the conference of the students of the State Free Worskshops (later VHKUTEMAS, the Higher State Art and Technical Workshops). 5 June 1920. (Republished from: Приключения «Черного квадрата» (Saint Petersburg: Palace Editions, 2007), p. 64).

The Black Square acquired for the members of UNOVIS nearly sacral meaning. One of the subjects in the curriculum of the Vitebsk Art School was exploring the Black Square; it was widely used as an emblem on UNOVIS's leaflets, publications and questionnaire forms. In 1920, the members of UNOVIS went from Vitebsk to Moscow to attend a confer- 
ence of the students of the State Free Workshops (later VHKUTEMAS, The Higher State Art and Technical Workshops) in a train coach that was decorated by Malevich's pupil Nikolai Suetin's design with a black square in the middle. ${ }^{44}$

Malevich's autobiographical myth achieved its culmination, which ascribed to the life of a private person the status of the chosen one, in his funeral, which the artist himself arranged as a symbolic act. ${ }^{45}$ Above Malevich's deathbed was placed the Black Square painting, which similarly to the Orthodox icon corner fulfilled the ritual function of a blessing. ${ }^{46}$ Malevich was buried in a Suprematist coffin, which was made according to his own drawings, with the Suprematist "Trinity" - the square, the circle and the cross - on its top (although the cross, as a religious symbol, was prohibited by the communist authorities). Each detail of the funeral ritual was determined and there was nothing arbitrary. Malevich's funeral costume included the base colours of Suprematism: white shirt, black trousers and red shoes. Malevich himself selected his grave site: under an old oak near the artist's summerhouse in the village of Nemchinovka, which was also highly symbolic. ${ }^{47}$

Malevich's body in the coffin was covered by a cloth bearing the image of the black square. The Black Square painting was placed on the radiator of the car that transported Malevich's coffin during the funeral procession in Leningrad, and a black square was painted on the train coach that took Malevich's coffin to Moscow. ${ }^{48}$ Nikolai Suetin designed the monument for Malevich's grave, again repeating the motif of the black square: here, it symbolised the conditionality of earthly life and the path to the other world. ${ }^{49}$ Thus, for his creator, Suprematism became the absolute truth, defining his (ritualistic) behaviour in different situations, and regulating his entire life - paradoxically, even after his death.

\footnotetext{
44 Татьяна Горячева, “Почти все о «Черном квадрате»”, 17.

45 Ibid.

46 Spira, The Avant-Garde Icon, 153.

47 Карасик, “Малевич в суждениях современников”, 194.

48 Горячева, “Почти все о «Черном квадрате»", 23.

49 Spira, The Avant-Garde Icon, 153.
} 
Fig. 5. Kazimir Malevich at his deathbed. May 1935. (Republished from: Приключения «Черного квадрата» (Saint Petersburg: Palace Editions, 2007), p. 57).

\section{SUPREMATISM AS A SUPREME RELIGION}

Malevich was a leading figure who claimed for himself the role of teacher and could not stand rivals: the need to impose Suprematism led him to propose his aesthetic system as the supreme truth. The religiosity of Suprematism was a construction of artistic mythology, which was generated spontaneously with a pragmatic purpose to justify Malevich's art conception as "truth", and it borrowed, for that purpose, archetypes from religious narratives.

Malevich's religiosity was very egocentric: identifying himself with Christ, he strove to write a new, Suprematist Gospel ${ }^{50}$; his writings

50 From Malevich's letter to Mikhail Matyushin (June 1916): "See, we don't yet have a book. But it's necessary, inexplicable. The book is the little history of our art. A new Gospel in art." (“Видите, книги еще нет у нас. А она нужна, необходима. Книга - это маленькая история нашего искусства. Новое Евангелие в искусстве.”) Казимир Малевич, “Письма к М. В. Матюшину”, Ежегодник Рукописного отдела Пушкинского Дома на 1974 год (Ленинград: Наука, 1976), 195. See also: Alexei Kurbanovsky, "Malevich's Mystic Signs: From Iconoclasm to New Theology", Sacred Stories: Religion and Spirituality in Modern Russia, eds. Mark D. Steinberg, Heather J. Coleman (Bloomington: Indiana University Press, 2007), 358-376. 
resembled sermons ${ }^{51}$. Malevich's dialogue with Christian ideas and symbols, e.g. in his frequent interpretations of the motif of the cross, was maintained in his entire body of work. He used the iconography of the Holy Face of Jesus - the face of the dolorous Christ - in his depictions of Russian peasants, doing this in the period when they suffered badly under forced collectivisation.

Malevich's relationship with religion was not limited to Christianity, but encompassed religion as a whole. He wrote about the approaching religious shift: "I visit churches, look at the saints and the whole active spiritual world, and I see in myself, and maybe in the world as a whole, that the moment for a change of religions has arrived." ${ }^{2}$ The new religion would be nothing less than Suprematism: "The moving of religions toward pure action becomes compulsory for me; the infinity of the action of religious spirit has a worldwide essence [...]. The people must be brought out from all the religions to the religion of pure action, in which there will be no rewards or promises. [...] I see in Suprematism, the three squares and the cross, a base not only for painting, but for everything, and the new religion." ${ }^{53}$ In the charts illustrating his "theory of the additional element", which demonstrated the evolution of modern art and the supremacy of Suprematism, Malevich stressed the independence of art, i.e. of Suprematism, both from religion and society ${ }^{54}$.

\section{AVANT-GARDE ARTIST AND SOCIALIST AUTHORITIES: THE COMPETITION OF TWO MYTHOLOGIES}

The rhetoric of the building of a new socialist state, which followed the revolution of 1917, was imbued with the pathos of the creation of the new world. Many cultural workers joined the revolution with the utopi-

51 Александра Шатских, “Казимир Малевич: Теоретическое и литературное наследие", Казимир Малевич: Живопись. Теория (Москва: Искусство, 1993), 185.

52 "Я посещаю церкви, смотрю на святых и на весь действующий духовный мир, и вот вижу в себе, а, может быть, в целом мире, что наступает момент смены религий.” Из Витебска в Москву, 11 апреля 1920 года (Malevich's letter to Mikhail Gershenzon, 11. IV 1920), http://kazimirmalevich. ru/bsp427/ (accessed on 17.08.2014). English translation quoted from: Yevgenia Petrova, "Personal Religiousness and Religious Consciousness among Russian Artists at the turn of the 20th Century", From Russia: French and Russian Master paintings 1870-1925, from Moscow and St Petersburg (London: Royal Academy of Arts, 2008), 170.

53 “Выход религий к чистому действу становится для меня обязательным, бесконечность действа религиозного духа является существом вселенским [...] я вижу в Супрематизме, в трех квадратах и кресте, начала не только живописные, но всего вообще; и новую религию.” Ibid. 54 Линда С. Бурсма, “Об искусстве, художественном анализе и преподавании искусства: Теоретические таблицы Казимира Малевича”, Казимир Малевич 1878-1935, 214. 
an belief of being able to build a new world, suggesting a new aesthetics aimed at positively transforming the living environment and the person within it. Avant-garde artists worked in the new administration, e.g. in different commissions and institutions dealing with the arts, education and heritage. The Museum and Institute of Artistic Culture and the VHKUTEMAS, The Higher State Art and Technical Workshops, were organised: Malevich worked in both of them. Participation in the work of institutions allowed him to contribute actively to discussions of the future of art and art education. The Suprematist system became, for a short time, a part of the state art curriculum.

The ambition of Suprematism was not just to serve socialism, but to guide it. Malevich's pupil El Lissitzky wrote in 1920: "At present we are living through an unusual period in time a new cosmic creation has become reality within ourselves which pervades our consciousness. [...] Suprematism - which embraces the totality of life's phenomena - will attract everyone away from the domination of work [...] it will liberate all those engaged in creative activity and make the world into a true model of perfection. This is the model we await from Kazimir Malevich. After the Old Testament there came the New - after the New the Communist - and after the Communist there follows finally the Testament of Suprematism" ${ }^{\prime \prime 5}$.

If Malevich's credo was that art must show the way to the revolution and future developments, then Constructivism, which arose after the revolution of 1917, saw its task as serving society, not being its spiritual leader. The Constructivists bound themselves to the Soviet authorities, which resulted in a transition (or fall) from individual artistic mythologies to the collective mythology, i.e. ideology. Malevich was accused of unilateralism in his teaching system, being attacked both by the supporters of a return to academic art education and by the Constructivists, whom he, in turn, accused of a lack of radicalism. While defending his positions, Malevich was forced to make concessions to ideology. He wrote about the "Red UNOVIS", which would establish a new art corresponding to the communist plan, revealing his wish to confront Red

55 El Lissitzky, "Suprematism in World Reconstruction", Russian Art of the Avant-Garde: Theory and Criticism 1902-1934, ed. John E. Bowlt (London: Thames and Hudson, 1991), 153, 158. 
Moscow and gain a leadership position not only in provincial Vitebsk, but also in the capital ${ }^{56}$.

After leaving Vitebsk and arriving in Petrograd in 1923, Malevich was appointed the director of the Museum of Artistic Culture, based on which in 1924 he initiated the State Institute of Artistic Culture. His activities during this period took place in sharp confrontation with the Constructivists, as well as with the supporters of traditional art. At the beginning of 1926, he was fired from his position as the director of the State Institute of Artistic Culture, and the institute itself was closed at the end of the same year: its collections were transferred to the State Russian Museum and the research departments to the State Institute of Art History. In the latter, Malevich worked from 1927 to 1929, but then both he and the research department directed by him were forced to leave the institute.

As the influence and self-confidence of the Soviet regime grew, there was no longer a need for the assistance of the avant-garde. Critics wrote that the Soviet people did not need a mystical philosophy of non-objective art, but a practical programme of useful material objects instead, and it became clear that abstract visual language was not the most suitable for transmitting the straightforward propaganda and didactic message of the authorities. Besides, as Boris Groys argues, the avant-garde was unacceptable to the Soviet authorities due to the competition of its prophetic pathos with that of communist ideology ${ }^{57}$.

Beginning in the second half of the 1920s, the avant-garde artists were removed from their positions in the state institutions and their exhibitions were prohibited. Some artists emigrated to the West; those who stayed were isolated from the official art life and had very few opportunities to earn a living. Socialist Realism was developed and was decreed the only correct style for Soviets: its purpose was to praise the Soviet state and its leaders using the eclectic language of realist traditions. The individual aesthetic utopia of the avant-garde artists clashed with the collective utopia of the Soviet regime, and was devoured by the latter.

Malevich, fallen into disfavour, struggled fiercely: in his defensive speeches, he compared himself to Giordano Bruno and was convinced

56 Василий Ракитин, “Малевич после анархизма”, Русский авангард: личность и школа (Санкт-Петербург: Palace Editions, 2003), 28.

57 Борис Гройс, "Русский авангард: прыжок через прогресс", Борис Гройс, Искусство утопии. (Москва: Художественный журнал, 2003), 33. 
that his art would secure him a place in history ${ }^{58}$. Even in the most difficult moments, he was not willing to abandon his role or give up pronouncing Suprematism to be the absolute truth; he used the rhetoric of a martyr suffering for the just cause: his mythology, having grown bigger than its creator, dictated his behaviour.

\section{CONCLUSION}

Analysis of the art practices and strategies of Malevich in terms of religious and mythological aspects significantly helps to clarify the essential mechanisms of Suprematism. Mythological aspects are revealed in both the general beliefs characteristic of the time and in personal conception of art, in the autobiographical myth of the artist and in individual artworks, which constitute micro-narratives that carry personal and/or collective mythologemes.

To its creator, the status of Suprematism was religious. Art practice was more than just art practice, it was a "life-building" that captured life in all its aspects: physical and functional, aesthetic and spiritual, social and political. Malevich's ambition was to elaborate an all-embracing system, a sort of cosmological model that would provide an ontological explanation and guidance for society. This is, in fact, the essential function of every mythology.

Elnara Taidre: Kazimir Malevich's Suprematism and Modernist Artistic Mythology as an Alternative to Religion

Keywords: Artistic Mythology, Modernism, Kazimir Malevich, Suprematism, Russian Avant-Garde, Utopia

\section{SUMMARY:}

The present paper discusses the religious and mythological aspects of the Suprematism of Kazimir Malevich (1879-1935). The purpose is to not to provide a broad and detailed overview of Malevich's artistic practices, but to focus on the tendency to mythologise. The Suprematist

58 Douglas, “Kazimir Malevich”, 36. 
art conception of Malevich radically changed the means of expression of visual art at the beginning of the $20^{\text {th }}$ century, conclusively breaking all connections with mimetic art and starting from scratch with the "language" of pure geometric forms. Therefore (and especially from the viewpoint of the current journal's central issue, dedicated to art and religion), of special interest is the fact that the formal innovations of Suprematism were motivated by impulses related to religious and, more broadly, mythological thinking.

CV:

Elnara Taidre is an art historian based in Tallinn. Her research interests include modern (Estonian) and contemporary art, and more specifically artistic mythologies in the visual arts of the $20^{\text {th }}$ century. She is currently a PhD student in Art History at the Estonian Academy of Arts and works as the keeper of the Research Support Collection of Prints and Drawings of the Art Museum of Estonia. Her recent projects include curating the exhibition Tõnis Vint and His Aesthetic Universe (2012, Kumu Art Museum, Tallinn, Estonia) and compiling the book of the same title that accompanied the exhibition. 